${ }^{2}$ Peacock M, Taylor GA, Brown W. Plasma 1,25(OH) $)_{2}$ vitamin D measured by radioimmunoassay and cytosol radioreceptor assay in normal subjects and patients with primary hyperparathyroidism and renal failure. Clin Chim Acta 1980;101:93-101.

${ }^{3}$ Adams PH, Jowsey J, Kelly PJ, Riggs BL, Kinney VR, Jones JD. Effect of hyperthyroidism on bone and mineral metabolism in man. $Q \mathcal{F} M e d$ $1967 ; 36: 1-15$.

4 Haldimann B, Kaptein EM, Singer FR, Nicoloff JT, Massry SG. Intestinal calcium absorption in patients with hyperthyroidism. $\mathcal{f}$ Clin Endocrinol Metab 1980;51:995-7.

5 Parfitt AM, Dent CE. Hyperthyroidism and hypercalcaemia. $Q \mathcal{F} \mathrm{Med}$ $1970 ; 39: 171-87$

(Accepted 28 April 1982)

MRC Mineral Metabolism Unit, The General Infirmary, Leeds LS1 3EX

R M FRANCIS, MB, MRCP, honorary registrar

M J BARNETT, BM, MRCP, senior house officer (present appointment: honorary registrar in oncology, Hackney Hospital, London E9)

P L SELBY, MA, MRCP, honorary registrar

M PEACOCK, MB, FRCP, acting director

\section{Serious cardiac morbidity in infectious mononucleosis}

Myocarditis is a recognised complication of infectious mononucleosis, but it is generally believed that there is "little to fear from cardiac complications." We report a case of serious cardiac morbidity as a result of infectious mononucleosis.

\section{Case report}

A 16-year-old schoolgirl was admitted to hospital because she had suddenly collapsed to the floor, without losing consciousness, and felt weak in the left arm and leg; her speech was slurred. Two weeks previously she had had a sore throat and painful, enlarged glands in her neck. Her mother had noticed that she had recently been breathless on exertion. On examination she was confused and dysarthric with a left hemiparesis. Her throat was inflamed and there were two palpable lymph glands, in the neck and axilla. Pulse was regular at 34 beats/min, and blood pressure was $155 / 85 \mathrm{~mm} \mathrm{Hg}$ Jugular venous pressure was not raised. The apex beat was displaced towards the anterior axillary line with both a left ventricular thrust and a right ventricular heave, and a pansystolic murmur was audible over the whole precordium.

Chest $x$-ray examination showed generalised cardiomegaly (cardiothoracic ratio 0.66 ), and an electrocardiogram showed complete heart block with

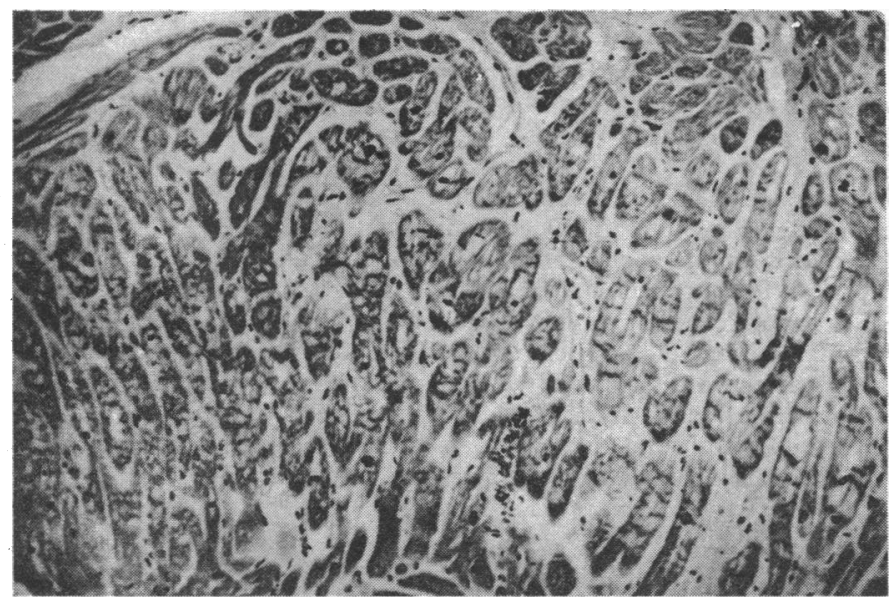

Left ventricular endomyocardial biopsy specimen, showing cytoplasmic degeneration, interstitial oedema, and a few inflammatory cells; myofibrils are enlarged up to $30 \mu$. Haematolylin and eosin; plastic-embedded section $\times 23$ (original magnification). total absence of atrial activity. A temporary pacing wire was inserted with immediate improvement in her conscious level. Anticoagulants were given because of the probability that a cerebral embolus from a left ventricular thrombus had occurred. Haemoglobin concentration was $10.9 \mathrm{~g} / \mathrm{dl}$ and white cell count $4.7 \times 10^{9} / 1$ with $43 \%$ lymphocytes, some atypical. A monospot test was positive, as was a Paul-Bunnell test at a titre of 1/224 (this was unchanged after absorption with guinea-pig antigen but fell to 1/7 after absorption with ox-cell antigen). Computed tomography showed an area of infarction in the right internal capsule. Cardiac catheterisation showed normal intracardiac pressures and no evidence of an intracardiac shunt, but ventricular angiograms showed dilated left and right ventricles with normal contractility. Histological examination of a left ventricular biopsy specimen (figure) showed enlarged myocardial fibres of up to $30 \mu$ and extensive cytoplasmic degeneration with some nuclear damage, and an oedematous interstitium containing a few inflammatory cells. These appearances suggested an acute process affecting the myocardial fibres compatible with myocarditis.

To confirm a diagnosis of recent infectious mononucleosis, further tests were undertaken at the Central Public Health Laboratory, Colindale. IgG antibody to Epstein-Barr virus capsid antigen was present to a titre of $1 / 256$, confirming that infection with Epstein-Barr virus had occurred at some time; specific $\operatorname{IgM}$ to Epstein-Barr virus capsid antigen was also present, indicating current or recent infection.

She was treated with steroids, but, as she remained totally dependent on the pacemaker, a permanent system was implanted. Seven months later she was well apart from breathlessness on moderate exertion, and physical examination was essentially normal apart from cardiomegaly, which was unchanged. A repeat left ventricular biopsy specimen on light microscopy showed no cytoplasmic degeneration, a few lymphocytes, and no apparent increase in fibrosis. Electron microscopy showed non-specific degenerative change with myofibrillar disorganisation and proliferation of mitochondria and moderate interstitial fibrosis.

\section{Comment}

Early reports of various complications in infectious mononucleosis have been criticised for lack of firm documentation of current infection." In our case there was sound haematological and serological confirmation of recent infection.

Electrocardiographic abnormalities in the form of non-specific ST and $\mathrm{T}$-wave changes and various degrees of heart block occur in up to $6 \%$ of patients with infectious mononucleosis. ${ }^{3}$ Few patients have symptomatic cardiac disease, and those who do appear to recover completely. ${ }^{1}$ Histological examination of hearts in these patients shows small, focal collections of lymphocytes in the myocardium. In the occasional case in which death has been attributed to heart disease ${ }^{4}$ interstitial oedema and myofibrillar degeneration are seen in addition to lymphocytes, as in our case.

Mason et al suggested that the presence of lymphocytes in an endocardial biopsy specimen may be an indication for steroid treatment, but our patient showed no benefit in terms of reduction of heart size, recovery of conduction tissue, or disappearance of lymphocytes in the second biopsy specimen. The near-normal appearance of the myocardium in the repeat biopsy specimen on light microscopy may reflect patchy disease of the heart tissue and sampling error.

We thank Dr J M B Edwards at the Virus Reference Laboratory, Colindale, for helping with the serological tests, and Miss A M Strong for her secretarial help. PJL is a British Heart Foundation junior research fellow.

${ }^{1}$ Houck GH. Involvement of the heart in infectious mononucleosis. Am $\mathcal{F}$ Med 1953;14:261-4.

2 Penman HG. Fatal infectious mononucleosis: a critical review. $f$ Clin Pathol 1970;23:765-71.

3 Hoagland RJ. Mononucleosis and heart disease. Am f Med Sci 1964;248: $35-40$.

4 Frishman W, Kraus ME, Zabkar J, Brooks V, Alonso D, Dixon LM. Infectious mononucleosis and fatal myocarditis. Chest 1977;72:535-8.

5 Mason JW, Billingham ME, Ricci DR. Treatment of acute inflammatory myocarditis assisted by endomyocardial biopsy. Am f Cardiol 1980;45 1037-44.

(Accepted 19 April 1982)

East Birmingham Hospital, Bordesley Green East, Birmingham B9 5ST

PATRICIA J LOWRY, MB, MRCP, research registrar, department of cardiovascular medicine

$C$ W EDWARDS, MD, MRCPATH, consultant pathologist

Regional Cardio-Thoracic Unit, Groby Road Hospital, Leicester M J GOLDBERG, MB, FRCP, consultant cardiologist 